\title{
Implementation of Geographic Information System for District and City Poverty Data Distribution Using the Rational Unified Process in West Java
}

\author{
Agnia Dwi Khasanah ${ }^{1 *}$, R.A.E Virgana Targa Sapanji ${ }^{2}$ \\ ${ }^{1,2}$ Faculty of Engineering, Widyatama University, Bandung, Indonesia \\ Corresponding author: *agnia.dwi@widyatama.ac.id \\ Received Date: 13 February 2021 \\ Accepted Date: 29 April 2021 \\ Published Date: 1 September 2021
}

\section{HIGHLIGHTS}

- The website-based Geographic Information System can display the distribution of poverty data in districts and cities in West Java.

- One of the Poverty Reduction Strategies is the availability of data that can be understood by the public.

- The Rational Unified Process is a software development method for creating a geographic information system website for poverty districts and cities in West Java

- Geographic Information Systems as a solution for mapping the distribution of any data so that it is easy to analyze and reprocess into other data.

\begin{abstract}
Poverty is a fundamental problem that several districts and cities have, especially in West Java province. One important aspect to support the Poverty Reduction Strategy is the availability of poverty data that is accurate and on target with good visualization so that it can facilitate the data analysis process. A websitebased Geographic Information System is the right solution for mapping the distribution of poverty data. Making this website using software development methods and the Rational Unified Process (RUP) with the Unified Modeling Language (UML) modeling language tool. For the maps, making process using Quantum GIS software and database storage using PostgreSQL. This website is expected to make it easier for the public to find the latest information and analyze poverty data, especially in districts and cities in West Java.
\end{abstract}

Keywords: Geographic Information Systems, Poverty, Rational Unified Process, QGIS

\section{INTRODUCTION}

The problem of poverty is complex and is multidimensional so that it becomes a development priority. The development programs carried out so far have always paid great attention to poverty alleviation efforts because basically the development carried out is aimed at improving the welfare of the community. One important aspect to support the Poverty Reduction Strategy is the availability of poverty data that is accurate and precisely targeted. A reliable measure of poverty is a formidable instrument for policymakers to focus attention on the living conditions of the poor. Good poverty data can be used to evaluate government policies on poverty, compare poverty across time and regions, and determine the target of the poor to improve their condition (Badan Pusat Statistika Provinsi Jawa Barat, 2019).

The poor are people who have an average expenditure per capita per month below the poverty line. The high number of people who move from one area to another can be one of the triggers of the development 
process that can encourage people to move to get access to basic infrastructure and other services such as employment, higher wages, education, and better access to health. The pandemic in 2020 also causes the number of poor people in Indonesia to increase. This was accompanied by many employees who experienced layoffs and changes in people's lifestyles during the pandemic, resulting in a decline in the economy in Indonesia. In the end, people with weak economic capacity will enter into the poor. Poverty now occurs not only in rural areas but in urban areas which are on the outskirts of the city or slum villages in the city center. Poverty is usually more widespread and deeper in very small cities than in very large cities or cities.

Geographic Information System have can connect various data at a certain point on earth, combine them, analyze and finally map the results using a computer-based system. During this pandemic, the Geographic Information System can greatly help the government or companies to adopt various policies using the Geographic Information System with spatial analysis techniques in the post-pandemic world (Ahasan \& Hossain, 2020). Therefore, the Geographic Information System is a solution for decision support tools to optimize data collected several parties or governments (Hatamleh et al., 2020).

The purpose of this study is to create a website based geographic information system that can map the distribution of poverty data including poverty lines, the number of poor people, the percentage of poor people, to the depth index and poverty severity. With this research, it is hoped that it can make it easier to find information about areas that are classified as poor, facilitate the process of updating information related to poverty, and assist the government in taking appropriate action.

\section{METHODOLOGY}

Detailed steps according to C. R. Kothari (Kothari, 2004) to provide a useful procedural guide in the process of this research. The software development method used to create this system is the Rational Unified Process (RUP) with the Union Modeling Language (UML) modeling language tool. The map-making process uses Quantum GIS (QGIS) Version 3.10 software, while for database storage using PostgreSQL. Quantum GIS is an open-source and free GIS-based software for geospatial data processing purposes (Astrini \& Oswald, 2012). The researcher conducted a literature survey related to this research, especially in the field of urban and district poverty in West Java from West Java Central Statistics Agency and West Java Province Open Data website.

\section{Rational Unified Process}

Rational Unified Process (RUP) is a process-oriented development method, carried out repeatedly, and focuses on the architecture it has. Figure 1 is the architecture owned by the Rational Unified Process.

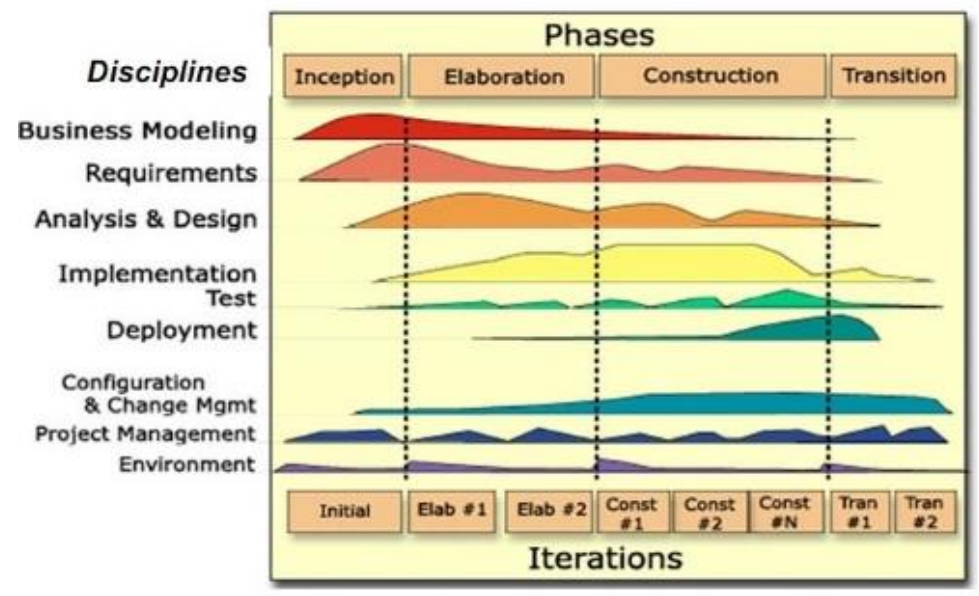

Figure 1: Architecture of Rational Unified Process (Kruchten, 2014) 
Rational Unified Process has 4 stages are Inception, Elaboration, Construction, and Transition. The following are the explanation of the stage and process:

1. Inception

The initial stage is to carry out business process modeling and collect the requirements of the system to be created (requirements). Activities carried out by researchers at this stage are determining the requirements of the geographic information system to be created. These needs include spatial data, digital maps, what databases will be created, and the menus that will be displayed on the website.

2. Elaboration

The planning stage of the system architecture, by analyzing and designing the system using UML diagrams, namely Use Case Diagrams, Activity Diagrams, Sequence Diagrams, and Class Diagrams.

3. Construction

The planning stage is focused on developing the components of the system to be created. Implementation and initial testing of the system to produce a product that suits your needs. The implementation of making this website uses soft coding on the Google Sites platform and the database used is the PostgreSQL database.

4. Transition

The transition stage is the installation or installation stage of the system. At this stage, user training, system maintenance, and evaluation are also carried out. After the website has been created and tested, periodic evaluations and maintenance are carried out for the sake of the latest data integrity.

\section{FINDINGS AND DISCUSSIONS}

This section will describe the results of the research that has been done. Based on the research results, data on the distribution of poverty in districts and cities in West Java has not been socialized in distribution maps or other visual forms. This makes the data accessible only in the form of a data table. This makes the data on the distribution of poverty in districts and cities in West Java, such as the number of poor people, the percentage, the poverty line, and their indexes, which are not directly understood by several parties, especially the community. This makes the public have to carry out further analysis to obtain the poverty information needed. The following is an example of data on the poverty line, the number of poor people, and the percentage of poor people in 30 Regencies and Cities in West Java in 2019 which were taken from the West Java Statistics Agency. 2 districts, namely Bogor and South Garut, and 1 city, namely Cikarang City, do not have specific data on poverty because they are new districts and cities in West Java.

Table 1: Data Samples for the Distribution of Poverty Lines Per Capita, Number of Poor Population, and Percentage of Poor Population in Districts and Cities in West Java in 2020 (Badan Pusat Statistika Provinsi Jawa

\begin{tabular}{|c|c|c|c|c|c|}
\hline No. & ID & District/City & $\begin{array}{l}\text { Poverty Line } \\
\text { Per Capita }\end{array}$ & $\begin{array}{c}\text { Number of Poor } \\
\text { Population (Thousand) }\end{array}$ & $\begin{array}{c}\text { Poor Population } \\
(\%)\end{array}$ \\
\hline 1 & 39 & Cianjur & 371699 & 234.5 & 10.36 \\
\hline 2 & 41 & Cirebon & 393452 & 247.9 & 11.24 \\
\hline 3 & 56 & Indramayu & 474807 & 220.3 & 12.7 \\
\hline 4 & 67 & Karawang & 466152 & 195.4 & 8.26 \\
\hline 5 & 85 & Kota Bandung & 500452 & 100 & 3.99 \\
\hline 6 & 96 & Kota Cimahi & 511375 & 31.6 & 5.11 \\
\hline 7 & 97 & Kota Cirebon & 457954 & 30.6 & 9.52 \\
\hline 8 & 131 & Kota Tasikmalaya & 470150 & 86.1 & 12.97 \\
\hline
\end{tabular}




\begin{tabular}{|c|c|l|c|c|c|}
\hline $\mathbf{9}$ & 142 & Kuningan & 352358 & 139.2 & 12.82 \\
\hline $\mathbf{1 0}$ & 157 & Majalengka & 453201 & 138.2 & 11.43 \\
\hline $\mathbf{1 1}$ & 193 & Purwakarta & 378287 & 80.2 & 8.27 \\
\hline $\mathbf{1 2}$ & 214 & Subang & 351885 & 149.8 & 9.31 \\
\hline $\mathbf{1 3}$ & 220 & Sumedang & 353092 & 118.4 & 10.26 \\
\hline $\mathbf{1 4}$ & 233 & Tasikmalaya & 323880 & 181.5 & 10.34 \\
\hline $\mathbf{1 5}$ & 252 & Kota Banjar & 544363 & 11.2 & 6.09 \\
\hline $\mathbf{1 6}$ & 253 & Kota Sukabumi & 328284 & 25.4 & 7.7 \\
\hline $\mathbf{1 7}$ & 254 & Sukabumi & 547399 & 175.1 & 6.68 \\
\hline $\mathbf{1 8}$ & 255 & Kota Bogor & 688194 & 75 & 2.45 \\
\hline $\mathbf{1 9}$ & 359 & Kota Depok & 367403 & 60.4 & 6.91 \\
\hline $\mathbf{2 0}$ & 403 & Bandung & 362212 & 263.6 & 10.49 \\
\hline $\mathbf{2 1}$ & 404 & Bandung Barat & 402877 & 479.5 & 0.69 \\
\hline $\mathbf{2 2}$ & 454 & Bogor & 0 & 0 & 7.62 \\
\hline $\mathbf{2 3}$ & 455 & Bogor Barat & 378108 & 91.4 & 8.99 \\
\hline $\mathbf{2 4}$ & 462 & Ciamis & 382264 & 36.1 & 9.98 \\
\hline $\mathbf{2 5}$ & 463 & Pangandaran & 0 & 0 & 0 \\
\hline $\mathbf{2 6}$ & 475 & Garut & 518667 & 186.3 & 4.82 \\
\hline $\mathbf{2 7}$ & 476 & Garut Selatan & 657953 & 134 & 0 \\
\hline $\mathbf{2 8}$ & 481 & Bekasi & 0 & 0 & \\
\hline $\mathbf{2 9}$ & 482 & Kota Bekasi & & & \\
\hline $\mathbf{3 0}$ & 483 & Kota Cikarang & & & \\
\hline
\end{tabular}

The system of geographic information on poverty in districts and cities in West Java is designed to use UML or Unified Modeling Language. UML diagrams are commonly used to describe system specifications because their graphical notation can facilitate a simple understanding of the system model (Sousa et al., 2017). There are two users in this system, namely the admin as the manager of the website and maps, and the public or other users who can view the maps on the completed website. Figure 2,3,4,5 is an example of a UML diagram, namely Use Case Diagrams, Activity Diagram of the View Maps, Sequence Diagram of the View Maps, and Class Diagrams from the Poverty GIS Website for District and City in West Java.

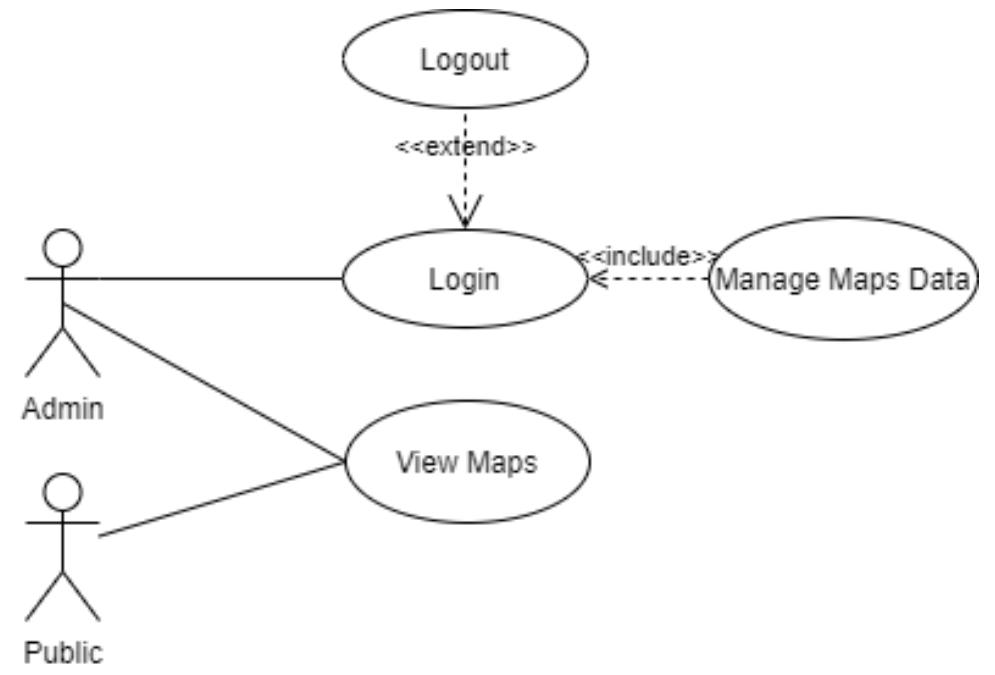

Figure 2: Use Case Diagram of the Poverty GIS Website for District and City in West Java 


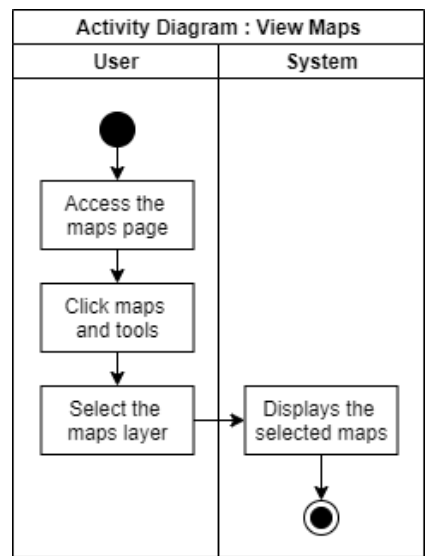

Figure 3: Activity Diagram of the View Maps

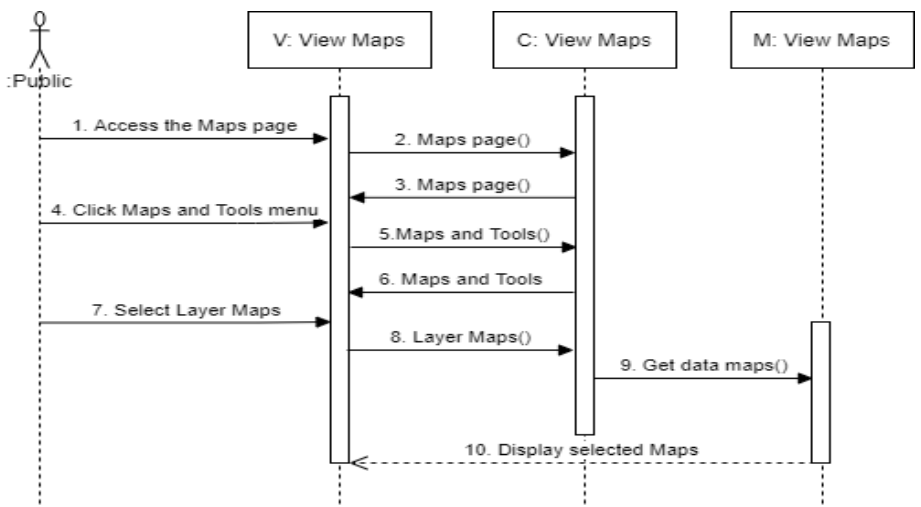

Figure 4: Sequence Diagram of the View Maps

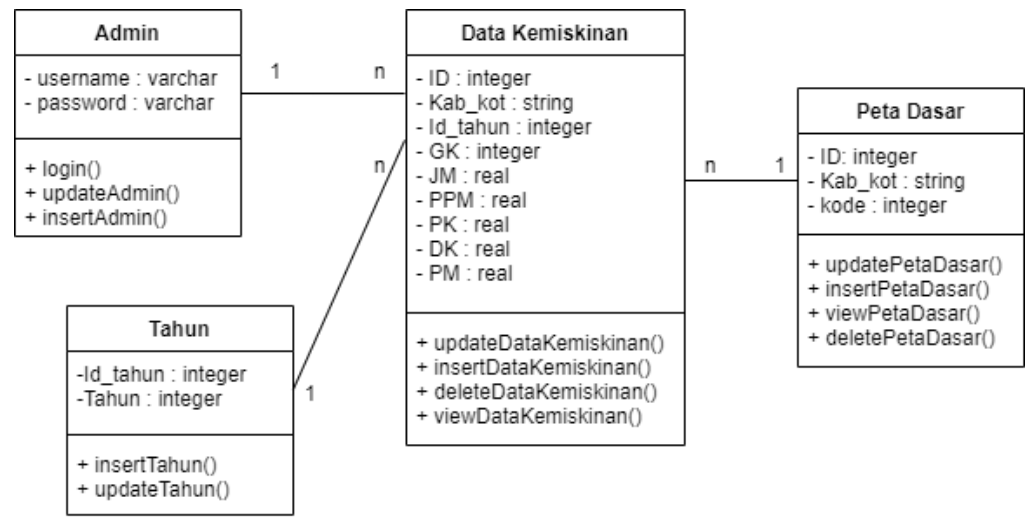

Figure 5: Class Diagram of the Poverty GIS Website for District and City in West Java

Figure 6 is the display form of the homepage or main page of the website of the City District Poverty Geographic Information System in West Java. This page contains some highlight information from poverty data for urban districts in West Java from 2019-2020. Figure 7 is a display of the Maps page, this page displays the distribution of poverty data in the form of maps using QGIS which can be accessed by the public and admin. Figure 8 is a display of the admin login page in the QGIS application, this is useful for managing map data. Figure 9 is a combined map of the analysis of per capita probability lines for 20202019. It also displays the legend and the distribution of data in each district and city in West Java. 


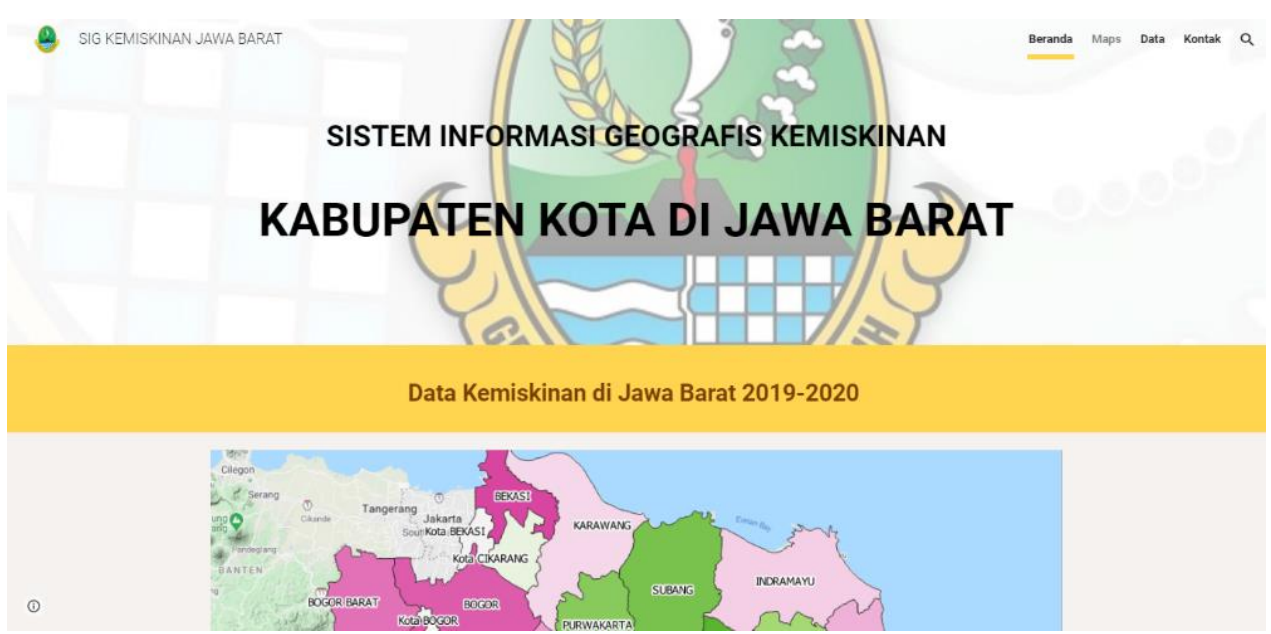

Figure 6: Display Home Page of the Poverty GIS Website for District and City in West Java

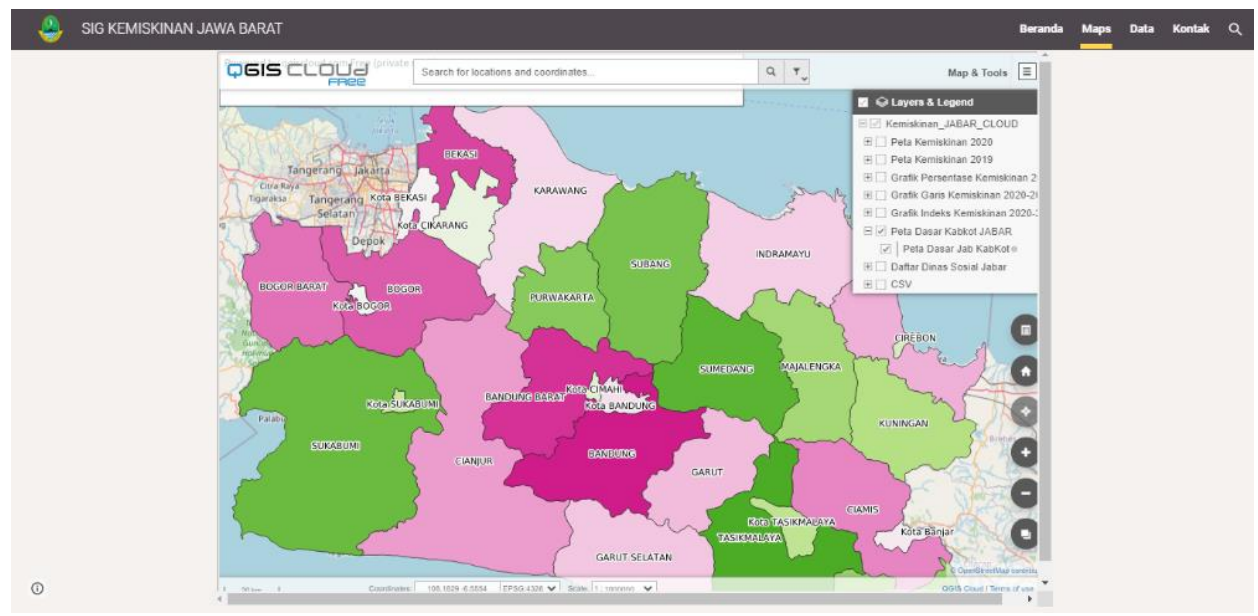

Figure 7: Display Maps Page of the Poverty GIS Website for District and City in West Java

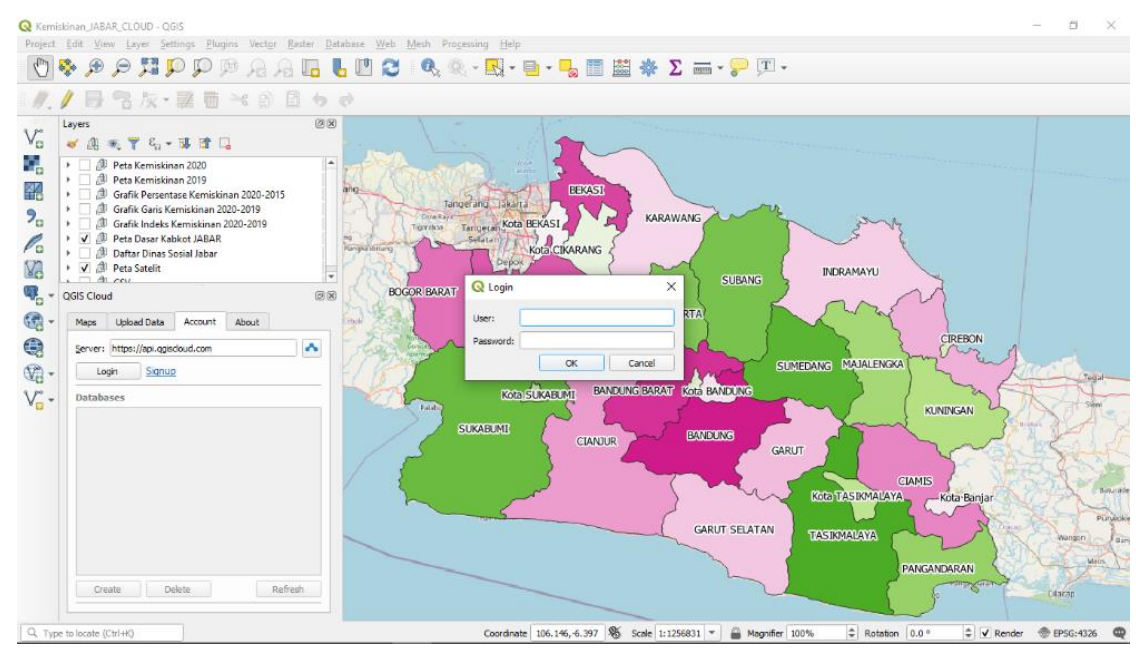

Figure 8: Display Login Admin in QGIS 


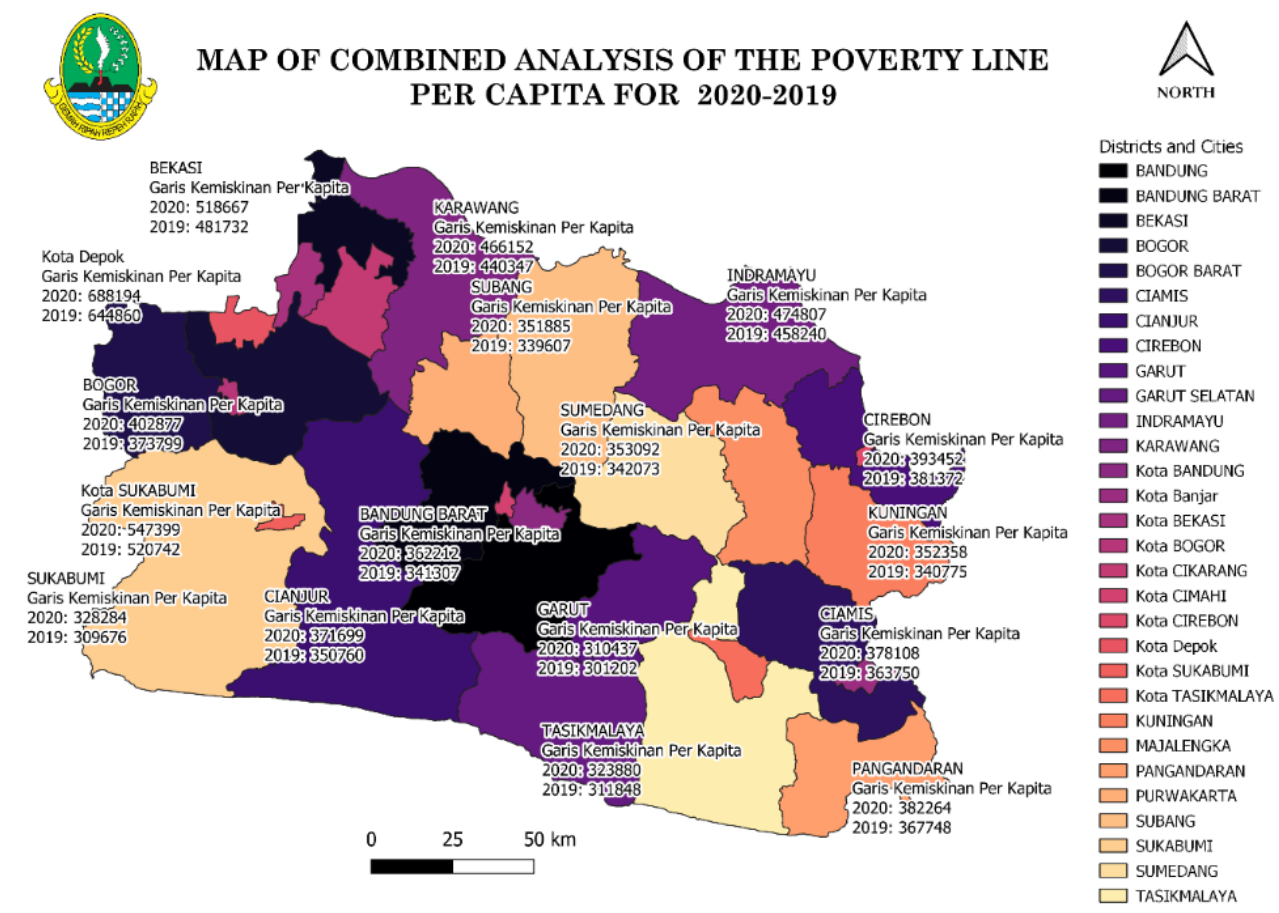

Figure 9: Map of Combined Analysis of the Poverty Line Per Capita for 2020-2019

In this research, website testing was also carried out using Black Box Testing to test the website so that it can function as expected. The test is to test the appearance, menu, function, and navigation on the website. The test results can be seen in tables 2 and 3 below:

Table 2: Testing Menu for Making Maps in QGIS

\begin{tabular}{|c|c|c|c|c|c|}
\hline No. & $\begin{array}{c}\text { Tested } \\
\text { Functions }\end{array}$ & Testing Scenarios & Expected Results & Test Results & Conclusion \\
\hline \multirow[t]{5}{*}{1} & \multirow[t]{5}{*}{ Login } & $\begin{array}{l}\text { Fill in the id and } \\
\text { password correctly, } \\
\text { then click "Ok". }\end{array}$ & $\begin{array}{l}\text { Login is successful } \\
\text { and can enter the } \\
\text { QGIS Cloud }\end{array}$ & $\begin{array}{l}\text { According to } \\
\text { expectations }\end{array}$ & Succeed \\
\hline & & $\begin{array}{l}\text { Fill in the wrong id } \\
\text { and password, then } \\
\text { click "Ok" }\end{array}$ & Login Failed & $\begin{array}{l}\text { According to } \\
\text { expectations }\end{array}$ & Succeed \\
\hline & & $\begin{array}{l}\text { Fill in the wrong id } \\
\text { and password, then } \\
\text { click "Ok" }\end{array}$ & Login Failed & $\begin{array}{l}\text { According to } \\
\text { expectations }\end{array}$ & Succeed \\
\hline & & $\begin{array}{l}\text { Fill in the wrong id } \\
\text { and wrong password, } \\
\text { then click "Ok" }\end{array}$ & Login Failed & $\begin{array}{l}\text { According to } \\
\text { expectations }\end{array}$ & Succeed \\
\hline & & $\begin{array}{l}\text { Leave the Id and } \\
\text { Password text boxes } \\
\text { blank, then click } \\
\text { "Ok". }\end{array}$ & Login Failed & $\begin{array}{l}\text { According to } \\
\text { expectations }\end{array}$ & Succeed \\
\hline
\end{tabular}




\begin{tabular}{|c|l|l|l|l|c|}
\hline 2 & $\begin{array}{l}\text { Manage } \\
\text { data: Add } \\
\text { Data }\end{array}$ & $\begin{array}{l}\text { Right-click on the } \\
\text { layer, then select } \\
\text { Open Attribute } \\
\text { Table. Click Toggle } \\
\text { Editing Mode. Select } \\
\text { the Add Feature } \\
\text { button. Enter the data } \\
\text { to be added. }\end{array}$ & $\begin{array}{l}\text { Data can be added to } \\
\text { the database and map } \\
\text { layer }\end{array}$ & $\begin{array}{l}\text { According to } \\
\text { expectations }\end{array}$ & Succeed \\
\hline 3 & $\begin{array}{l}\text { Manage } \\
\text { data: Edit } \\
\text { Data }\end{array}$ & $\begin{array}{l}\text { Right-click on the } \\
\text { layer, then select } \\
\text { Open Attribute } \\
\text { Table. Click Toggle } \\
\text { Editing Mode. Select } \\
\text { the data to be } \\
\text { changed. }\end{array}$ & $\begin{array}{l}\text { Data can be } \\
\text { converted and } \\
\text { updated into a } \\
\text { database and layer } \\
\text { maps }\end{array}$ & $\begin{array}{l}\text { According to } \\
\text { expectations }\end{array}$ & Succeed \\
\hline $\mathbf{4}$ & $\begin{array}{l}\text { Right-click on the } \\
\text { layer, then select } \\
\text { Open Attribute } \\
\text { Tata: Clear } \\
\text { Data }\end{array}$ & $\begin{array}{l}\text { Editing Mode. Select } \\
\text { the data to be deleted, } \\
\text { then click the Delete } \\
\text { Field. }\end{array}$ & $\begin{array}{l}\text { Data can be deleted } \\
\text { from databases and } \\
\text { layer maps }\end{array}$ & $\begin{array}{l}\text { According to } \\
\text { expectations }\end{array}$ & Succeed \\
\hline
\end{tabular}

Table 1: Website Testing Menu

\begin{tabular}{|c|c|c|c|c|c|}
\hline No. & $\begin{array}{c}\text { Tested } \\
\text { Functions }\end{array}$ & Testing Scenarios & Expected Results & Test Results & Conclusion \\
\hline \multirow[t]{2}{*}{1} & \multirow[t]{2}{*}{$\begin{array}{l}\text { Displays a } \\
\text { website }\end{array}$} & $\begin{array}{l}\text { Enter the browser, then } \\
\text { type the name of the } \\
\text { website correctly }\end{array}$ & $\begin{array}{l}\text { The browser can } \\
\text { display web pages }\end{array}$ & $\begin{array}{l}\text { According to } \\
\text { expectations }\end{array}$ & Succeed \\
\hline & & $\begin{array}{l}\text { Enter the browser, then } \\
\text { type the wrong website } \\
\text { name }\end{array}$ & $\begin{array}{l}\text { The browser } \\
\text { cannot display the } \\
\text { page website } \\
\text { (Error) or not } \\
\text { display the proper } \\
\text { website }\end{array}$ & $\begin{array}{l}\text { According to } \\
\text { expectations }\end{array}$ & Succeed \\
\hline 2 & $\begin{array}{l}\text { Displays the } \\
\text { home page }\end{array}$ & $\begin{array}{l}\text { Access the home page } \\
\text { via Home menu } \\
\text { navigation }\end{array}$ & $\begin{array}{l}\text { The browser can } \\
\text { display the home } \\
\text { page }\end{array}$ & $\begin{array}{l}\text { According to } \\
\text { expectations }\end{array}$ & Succeed \\
\hline 3 & $\begin{array}{l}\text { Displays the } \\
\text { Maps page }\end{array}$ & $\begin{array}{l}\text { Access the home page } \\
\text { via the Maps menu } \\
\text { navigation }\end{array}$ & $\begin{array}{l}\text { The browser can } \\
\text { display the Maps } \\
\text { page }\end{array}$ & $\begin{array}{l}\text { According to } \\
\text { expectations }\end{array}$ & Succeed \\
\hline 4 & $\begin{array}{l}\text { Displays the } \\
\text { Data page }\end{array}$ & $\begin{array}{l}\text { Access the home page } \\
\text { via Data menu } \\
\text { navigation }\end{array}$ & $\begin{array}{l}\text { The browser can } \\
\text { display the Data } \\
\text { page }\end{array}$ & $\begin{array}{l}\text { According to } \\
\text { expectations }\end{array}$ & Succeed \\
\hline
\end{tabular}




\begin{tabular}{|c|l|l|l|l|c|}
\hline $\mathbf{5}$ & $\begin{array}{l}\text { Displays the } \\
\text { Contact page }\end{array}$ & $\begin{array}{l}\text { Access the home page } \\
\text { via the Contacts menu } \\
\text { navigation }\end{array}$ & $\begin{array}{l}\text { The browser can } \\
\text { display the } \\
\text { Contact page }\end{array}$ & $\begin{array}{l}\text { According to } \\
\text { expectations }\end{array}$ & Succeed \\
\hline $\mathbf{6}$ & $\begin{array}{l}\text { Button View } \\
\text { Maps }\end{array}$ & $\begin{array}{l}\text { Click the View Maps } \\
\text { button on the Home } \\
\text { page to access the Maps } \\
\text { page }\end{array}$ & $\begin{array}{l}\text { The website can } \\
\text { redirect to the } \\
\text { Maps page }\end{array}$ & $\begin{array}{l}\text { According to } \\
\text { expectations }\end{array}$ & Succeed \\
\hline $\mathbf{7}$ & $\begin{array}{l}\text { Button View } \\
\text { Data }\end{array}$ & $\begin{array}{l}\text { Click the View Data } \\
\text { button on the Home } \\
\text { page to access the Data } \\
\text { page }\end{array}$ & $\begin{array}{l}\text { The website can } \\
\text { redirect to the } \\
\text { Data page }\end{array}$ & $\begin{array}{l}\text { According to } \\
\text { expectations }\end{array}$ & Succeed \\
\hline $\mathbf{8}$ & $\begin{array}{l}\text { Button Zoom } \\
\text { in Maps }\end{array}$ & $\begin{array}{l}\text { Click the Enlarge Maps } \\
\text { button on the Maps page } \\
\text { to enlarge the Maps } \\
\text { view. }\end{array}$ & $\begin{array}{l}\text { The website can } \\
\text { point to the QGIS } \\
\text { Cloud link }\end{array}$ & $\begin{array}{l}\text { According to } \\
\text { expectations }\end{array}$ & Succeed \\
\hline $\begin{array}{l}\text { View maps of } \\
\text { poverty data } \\
\text { distribution }\end{array}$ & $\begin{array}{l}\text { Enter the Maps page } \\
\text { then select the Maps } \\
\text { menu. Click the legend } \\
\text { in the top right (Maps } \\
\text { and Tools). Select the } \\
\text { Maps you want to } \\
\text { display. }\end{array}$ & $\begin{array}{l}\text { The selected maps } \\
\text { are displayed } \\
\text { successfully }\end{array}$ & $\begin{array}{l}\text { According to } \\
\text { expectations }\end{array}$ & Succeed \\
\cline { 3 - 6 } & $\begin{array}{l}\text { Enter the Maps page } \\
\text { then select the Maps } \\
\text { menu. Do not click the } \\
\text { legend in the upper right } \\
\text { (Maps and Tools). }\end{array}$ & $\begin{array}{l}\text { Maps are } \\
\text { displayed only at } \\
\text { the beginning }\end{array}$ & $\begin{array}{l}\text { According to } \\
\text { expectations }\end{array}$ & Succeed \\
\hline
\end{tabular}

\section{CONCLUSION AND RECOMMENDATIONS}

The website of the District and City Poverty Geographic Information System in West Java can display the distribution of poverty data through visualization of the map that looks more attractive. With this system, it makes it easier for the public to find information and analyze data on areas that have high or low poverty levels. Besides, the Geographic Information System Website can be used as a solution to the process of updating the publication of data related to poverty or other data as a form of data transparency or data openness from the government. Furthermore, it is necessary to carry out regular maintenance and evaluation to maintain the integrity and updating of the data according to the publication of the Central Statistics Agency of West Java Province and the Office that covers poverty problems.

\section{ACKNOWLEDGMENTS}

This research was written by Agnia Dwi Khasanah, a student of the Information Systems Department with Mr. R.A.E Virgana Targa Sapanji, S.Kom., M.T., the lecturer of Information Systems Department, Faculty of Engineering, Widyatama University Bandung. The research data was taken from the West Java Statistics Center (Badan Pusat Statistika Provinsi Jawa Barat). This study did not receive specific grants from funding agencies in the public, commercial or non-profit sector. 


\section{REFERENCE}

Ahasan, R., \& Hossain, M. M. (2020). Leveraging GIS and spatial analysis for informed decision-making in COVID-19 pandemic. Health Policy and Technology, 10(1), 7-9. https://doi.org/10.1016/j.hlpt.2020.11.009

Astrini, R., \& Oswald, P. (2012). Modul Pelatihan Quantum GIS Tingkat Dasar Untuk Pemetaan Evakuasi Tsunami. BAPPEDA Provinsi NTB.

Badan Pusat Statistika Provinsi Jawa Barat. (2019). Kemiskinan Kabupaten dan Kota Di Jawa Barat Tahun 2014-2019 (Badan Pusat Statistika Provinsi Jawa Barat (ed.); 130617.32). Badan Pusat Statistik Provinsi Jawa Barat. https://jabar.bps.go.id

Badan Pusat Statistika Provinsi Jawa Barat. (2021). Provinsi Jawa Barat Dalam Angka 2021 (Badan Pusat Statistika Provinsi Jawa Barat (ed.); 2021st ed.). Badan Pusat Statistik Provinsi Jawa Barat. https://jabar.bps.go.id

Hatamleh, R. I., Jamhawi, M. M., Al-Kofahi, S. D., \& Hijazi, H. (2020). The Use of a GIS System as a Decision Support Tool for Municipal Solid Waste Management Planning: The Case Study of Al Nuzha District, Irbid, Jordan. Procedia Manufacturing, 44, 189-196. https://doi.org/10.1016/j.promfg.2020.02.221

Kothari, C. R. (2004). Research Methodology: Methods and Techniques (Second Rev). New Age International (P) Limited.

Kruchten, P. (2014). The Rational Unified Process--An Introduction. Rational Software, January 20, 11. https://www.researchgate.net/publication/220018149

Sousa, T. C. de, Kelvin, L., Dias Neto, C., \& Giovanni N. de Carvalho, C. (2017). A Formal Semantics for Use Case Diagram Via Event-B. Journal of Software, 12(4), 189-200. https://doi.org/10.17706/jsw.12.3.189-200

Website Link: bit.ly/GISK JABAR

Online Maps (QGIS Cloud) Link: bit.ly/QGISCloud_KJabar 